Katarzyna Piotrowska1 $^{1}$, Lukasz Pabianek ${ }^{2} \mathbb{D}$

\title{
Physical activity - classification, characteristics and health benefits
}

\author{
${ }^{1}$ Collegium Medicum in Bydgoszcz, Nicolaus Copernicus University in Toruń, \\ Poland \\ ${ }^{2}$ Institute of Physical Culture, Kazimierz Wielki University in Bydgoszcz, Poland
}

\begin{abstract}
Regular physical activity is associated with numerous health benefits for both women and men. By regularly engaging in physical activity, we delay overall mortality and improve well-being in any population. The size of the observed adaptive changes resulting from the implemented physical activity is very large, and its benefits are numerous. Appropriate level of physical activity should be maintained throughout life due to its ability to inhibit the natural aging process and slow down the lesions observed with age.

The purpose of this work is to illustrate the natural components of physical fitness and physical activity, with particular emphasis on its impact on health and wellbeing.
\end{abstract}

Keywords: physical fitness development, physical training, health

\section{Introduction}

Striving to lead an active lifestyle, which is essential for our intellectual and physical fitness nowadays, should be inseparable and obvious through the use of recreational physical activity. Today, determining physical fitness translates into a view that is associated with the functioning of the locomotor system, but also with the proper responses of the human body. We also perceive it as: learned movement exercises, the level of condition of systems and organs, proper motor skills (Osiński 2003).

Undertaking physical activity mostly involves work or everyday activities. The modern development of technology means that the pace of people's lives is constantly increasing. The phenomenon applies to both children, teenagers and adults. This phenomenon may have a positive impact on the sphere of intellectual abilities of younger generations, while in other age groups it is associated with regression of physical fitness and loss of health.

Physical fitness, which is expressed through the functional capacity of the body can be represented as a set of individual characteristics. Efficiency has been

\footnotetext{
${ }^{1}$ Katarzyna Piotrowska, ORCID: 0000-0002-7752-7244

${ }^{2}$ Lukasz Pabianek, e-mail: lukasz.pabianek@gmail.com, ORCID: 0000-0001-8513-9551
} 
defined in many articles over a dozen or so years, but for the most part it is considered a very important attribute or trait with the ability to perform physical activity (Barengo 2005). These are not only high results in motor tests, but also an appropriate pro-health attitude (Czaplicki 2003).

Regular physical activity is associated with numerous health and psychological benefits, for both women and men. By regularly engaging in physical activity, we delay overall mortality. This is also the case when the individual increases effort by changing the lifestyle of sitting or insufficient activity (Ainsworth and co. 2000).

Many studies around the world have shown that there is a positive correlation between low physical fitness and coordination disorders, unsatisfactory sports results, as well as diseases (Barengo 2005; Kochanowicz 2007; Klimczyk 2007).

Pointing to parents, as well as their ignorance of the definition of human health and the needs of the body, we see an unfavorable trend among children and adolescents, which is reproduced in their later life and passed on to the next generation. Due to the ignorance of the beneficial effects of exercise on health; posture defects, impaired immunity, allergies, respiratory and circulatory disorders are more and more frequently encountered (Roberts 2005).

\section{Physical fitness - classification}

Motorism is a set of features of a given unit, thanks to which it performs daily activities without excessive fatigue. The most important components of physical fitness are the work of muscle groups through which we walk, run, and throw and daily manual activities that are an integral part of life (Osiński 2000).

A group of researchers and scientists described the definition of physical fitness, Trześniowski 1953 describes that "Physical fitness is a human readiness to undertake and solve difficult movement tasks in various life situations requiring strength, speed, dexterity, agility, endurance, as well as certain acquired and shaped motor skills and habits based on appropriate motor skills and health. " On the other hand, the definition given by Drozdowski (1987) is worded as follows: "Physical fitness is a determinant of human biological values".

When analyzing motor skills, one cannot ignore the fact that they are largely conditioned by innate factors, including:

- adaptability of the nervous system,

- maintaining optimal $\mathrm{pH}$ in the body,

- regulation of the most important systems, i.e. respiratory and circulatory,

- metabolism,

- body type (ectomorph, endomorph, mesomorph),

- genetic predisposition,

- $\quad$ temperament (Drozdowski 2002).

Among motor skills we can refer to the division into two groups that are the most characteristic: 
- fitness talents: strength, speed and endurance (determined by phenotypic factors),

- coordination skills: a sense of balance of rhythm, orientation and rhythm, correct reaction speed, dexterity, flexibility,

J. Szopa in an interesting way presented the motor skills that fall into four subgroups, they are:

1. Strength skills,

2. Speed giftedness,

3. Endurance skills,

4. Coordination skills (Szopa 1996).

$\underline{\text { Strenght skills }}$

Strength is "the ability to overcome external resistance or counteract it at the expense of muscular effort" (Drozdowski 2002 p. 59).

There are different properties of operating forces, including:

- Static force - depends on increased hypertonia (muscle tone) e.g. dynamometer compression,

- Explosive force - the ability to generate large decks of strength in the shortest possible time, eg javelin throw,

- Dynamic strength - the ability to perform high resistance at high speed Speed giftedness (also known as power), eg a squat jump (Sozański 1999).

Speed is "the ability of a person to make moves in a minimum time period for given conditions. It is assumed that the task does not last long and does not cause fatigue "(Drozdowski 2002, p. 59).

The most important factor determining speed is the muscular system - bound with him the morphological structure, as well as the ratio of red fibers to white fibers. Speed is affected by the following:

- response time - this is the period of time that passes from the moment the stimulus occurs to the time the motion is triggered - the action is performed. This is an innate trait, practically not susceptible to training activities,

- $\quad$ speed of a single move - depends on muscle structure and occurrence of white and red fibers in it,

- frequency of movement - illustrates the number of movement cycles performed at a given time, e.g. swimming for $50 \mathrm{~m}$, number of kicks per time unit (Latach 2003, Orzech 1998).

Endurance skills

Among the publications related to sports, a distinction is made between::

- general endurance,

- $\quad$ special endurance (Sozański 1999).

Endurance is defined by the ability to "perform long-term work without reducing performance" (Drozdowski 2002, str 60).

The specificity of endurance depends on the glycogen reserves the muscle contains (Sozański 1999). However, it is undoubted that a big role is played by human decisionmaking, i.e. related to will. It is used during extreme tiredness, pain symptoms related to effort (Naglak 1979). 
The term general endurance defines the ability to engage large muscle groups during physical work that is carried out for a long time (Sozański 1999).

The period of special endurance is reserved for specific physical effort in a given sport, in which specific adaptations are required. Special strength consists of the specificity of the human body, movement technique, time and intensity of effort. Additionally, it can be divided into:

- $\quad$ speed endurance,

- strenght endurance,

- coordination endurance (Sozański 1999, Naglak 1979).

Coordination capacity

The most widely understood coordination can include eye-hand and eye-spatial coordination, which are associated with motor skills such as dexterity and agility. Through acquired skills it is possible to make complex movements, develop balance and sense of rhythm as well as combine a series of movements.

We define agility as a feature thanks to which we have the ability to react quickly to a stimulus, perform precise movements at various levels of advancement.

Dexterity is defined as the ability to perform economic movements, with due diligence (Drozdowski 2002).

Flexibility

Flexibility - this term means the body's ability to obtain a large amplitude in its motor activities. Flexibility activities are to immunize the ligament apparatus to perform activities during take-offs (Latach 2003, Drozdowski 2002).

Shaping flexibility is conditioned by specific factors, including:

- $\quad$ soft tissue flexibility (ligaments, tendons),

- muscle group present at a given joint,

- gender and age,

- body temperature and muscle group,

- the amount of muscle tissue,

- $\quad$ body type (Ljach 2003).

The level of physical fitness should be maintained throughout life due to the work performed every day, participation in social life in an active way, as well as due to emerging diseases and the body's ability for regeneration (Ortega and co. 2008). The degree of physical fitness can be determined using the following tests:

- $\quad$ MTSF - International Physical Fitness Test,

- $\quad$ EUROFIT - European Physical Fitness Test,

- Chromiński's test,

- Zuchory's efficiency indexes,

- $\quad$ Progressive tests:

$\rightarrow$ ergometer

$\rightarrow$ mechanical treadmill

$\rightarrow \quad$ rowing machine ( Jastrzębska, Zatoń 2014).

A popular way to check physical fitness for several years is walking. It is the basic and most widely available form of aerobic exercise, it easily allows you to adjust the pace to age, training. It can be used by most people who do not have 
contraindications to it. During the march, the body burns a comparable amount of calories, as if running a similar distance. It has become popular to measure physical activity using a pedometer (pedometer), which is used to count steps performed during the day (Table 1) (Plewa, Markiewicz 2006).

Table 1. Pedometer indications according to Leermakers and all 2000

\begin{tabular}{cc}
\hline Physical activity & Number of steps per day \\
\hline Lack & $<3000$ \\
\hline Low & $3000-6000$ \\
\hline Moderate & $6001-10000$ \\
Recommended & $>10000$ \\
Causing weight loss & $12000-15000$ \\
\hline
\end{tabular}

\section{The role of physical fitness as a factor shaping health}

The positive relationship between physical activity and health is no longer debatable. People who undertake physical activity at a sufficient level obtain a wide set of benefits for physical and mental health compared to inactive people (Bouchard and co. 1990).

Any physical activity is associated with energy expenditure, which contributes to weight reduction. The advantages of taking physical activity can be:

body recomposition, improvement of glucose tolerance (IGT), lipid profile and insulin value, normalization of resting and exercise blood pressure and pulse,

facilitating dietetic nutrition due to the increased caloric content of the diet, mood improvement,

improvement of emotional, mental and social condition (Plewa, Markiewicz 2006).

Physical fitness is often genetically determined, however, it can largely depend on environmental factors. Childhood and adolescence are the key periods of life because the most important physiological and psychological changes occur during this time. Lifestyles, healthy / not healthy behaviors become established in these years, which may later affect health behaviors as adults (Ortega and co. 2008).

Physical fitness, exercise and physical activity are often used in literature as interchangeable concepts, which is not always right. Physical fitness is the ability to perform broadly understood physical activity, referring to physiological and psychological characteristics. Physical activity is any movement that the body produces through the action of muscles, in effect expending energy. Physical exercises refers to previously planned, organized, systematic and purposeful physical activity.

The most common health-related components are: cardio-respiratory capacity, muscular efficiency and speed, agility (Ortega and co. 2008).

There is conclusive evidence that regular physical activity is effective in preventing cardiovascular disease, diabetes, cancer, hypertension, obesity, depression, osteoporosis, and premature death. The relationship between physical activity and the state of health is expressed in a linear way, as follows: the more often physical activity 
and the associated the greater the physical fitness, the greater the improvement in health (Warburton and co. 2006).

Physical inactivity is the fastest modifiable risk factor for a range of diseases. Inactivity in society is up to $51 \%$, this is the highest modifiable risk factor (Blair 2001).

Cardio-respiratory or cardiovascular efficiency is the total capacity of the cardiovascular and respiratory systems and the ability to perform long and exhausting exercises. VO2max - i.e. maximum oxygen consumption has been recognized by the World Health Organization as the best indicator of cardiovascular fitness. The most common way to express it is the amount of oxygen consumed per unit of time in relation to body weight (Ortega and co. 2007). Being fit or active reduces the risk of illness by $50 \%$. In addition, an increase in energy expenditure related with physical activity reduces mortality from cardiovascular diseases by $20 \%$. In middle-aged, physically inactive women, a 52\% increase in cardiovascular mortality and a $29 \%$ increase in cancer mortality have been reported, compared to physically active women. It was caused by, among others sedentary lifestyle, smoking (Hu 2004).

Aerobic and resistance exercises have contributed to reducing the risk of type 2 diabetes.

This relationship was particularly noticeable in people at high risk. Moderate exercise, about 40 minutes a week, prevents type 2 diabetes from developing in middle-aged men (Manson 1992).

It is very likely that recreational physical activity in the form of part of work and leisure contributes to a reduction in the incidence of colon cancer and breast cancer. (Thune, Furberg 2001).

Load and resistance exercises most affect bone mineral density. Sport tends to increase bone mineral density, which reduces the risk of fractures (Wolf and co. 1999).

Physical fitness has a positive effect on the state of well-being, contributes to the performance of daily duties as well as improving sports performance.

Sedentary lifestyle and insufficient physical activity undoubtedly contribute to the development of a number of disease entities (including diabetes, obesity, hypertension, osteoporosis). It also affects our well-being and affects the level of immunity. A global group of experts estimated that young people should do about 60 min / day of moderate physical activity (examples of energy expenditure in Table 2) in order to maintain adequate physical comfort and mental helth (Biernat, Stupnicki 2005).

\section{Summary}

Regular physical activity is associated with numerous health benefits. By regularly engaging in physical activity, overall mortality is being delayed. Undoubtedly, various forms of physical activity should be implemented, adapted to gender and age, in order to prevent health disorders and maintain well-being. Understanding the role of physical activity in modern society is one of the most important tasks of health and recreation promoters to prevent civilization diseases and to promote a long, healthy life. 


\section{References}

Ainsworth, B. E., Haskell, W. L., Whitt, M. C., Irwin, M. L., Swartz, A. M., Strath, S. J., Jacobs, D. R. (2000). Compendium of physical activities: an update of activity codes and MET intensities. Medicine and science in sports and exercise, 32(9; SUPP/1), 498-504.

Barengo, N. C., Hu, G., Kastarinen, M., Lakka, T. A., Pekkarinen, H., Nissinen, A., Tuomilehto, J. (2005). Low physical activity as a predictor for antihypertensive drug treatment in 25-64-year-old populations in eastern and south-western Finland. "Journal of hypertension", 23(2), 293-299.

Biernat, E., Stupnicki, R. (2005). Przegląd międzynarodowych kwestionariuszy stosowanych w badaniu aktywności fizycznej., Wychowanie Fizyczne i Sport", 49(2), 61-73.

Bouchard, C., Shephard, R. J., Stephens, T., Sutton, J. R., McPherson, B. D. (1990). Exercise, fitness, and health: a consensus of current knowledge: proceedings of the International Conference on Exercise, fitness, and health, Human Kinetics Publishers.

Czaplicki, Z. (2003). Rozwój motoryczny dzieci i młodzieży w procesie ontogenezy „Lider”, (4), 28-29.

Drozdowski Z. (1997), Biologiczny rozwój człowieka. AWF Poznań. Skrypty, 102.

Drozdowski Z. (2002) „Antropologia dla nauczycieli wychowania fizycznego”. Poznań

Hu, F. B., Willett, W. C., Li, T., Stampfer, M. J., Colditz, G. A., \& Manson, J. E. (2004). Adiposity as compared with physical activity in predicting mortality among women. "New England Journal of Medicine", 351(26), 2694-2703.

Jastrzębska, A., Zatoń, M. (2014). Testy fizjologiczne w ocenie wydolności fizycznej. Wydawnictwo Naukowe PWN, Warszawa.

Klimczyk M. (2007) Ocena rozwoju fizycznego, a przygotowanie sportowe skoczków o tyczce w wieku 11-14 lat. W „Pohyb a Zdrapie - IV. roćnik” - Trenćin, Tranćin.

Kochanowicz K., Klimczyk M. (2007) Sprawność fizyczna, a wynik sportowy tyczkarzy w wieku 11-14 lat. Ruch rzeźbi ciało i umysł. Leszczyńskie stowarzyszenie „Dzieciom niepełnosprawnym”. Leszno.

Ljach W. (2003). Kształtowanie zdolności motorycznych dzieci i młodzieży. Centralny Ośrodek Sportu, Warszawa.

Manson, J. E., Nathan, D. M., Krolewski, A. S., Stampfer, M. J., Willett, W. C., Hennekens, C. H. (1992). A prospective study of exercise and incidence of diabetes among US male physicians. Jama, 268(1), 63-67.

Naglak, Z. (1979). Trening sportowy: teoria i praktyka. Państwowe Wydawnictwo Naukowe.

Ortega, F. B., Artero, E. G., Ruiz, J. R., Vicente-Rodriguez, G., Bergman, P., Hagströmer, M., Polito, A. (2008). Reliability of health-related physical fitness tests in European adolescents. the HELENA Study. "International journal of obesity", 32(S5), S49.

Ortega, F. B., Ruiz, J. R., Castillo, M. J., Sjöström, M. (2008). Physical fitness in childhood and adolescence: a powerful marker of health. "International journal of obesity", 32(1), 1. 
Ortega, F. B., Ruiz, J. R., Mesa, J. L., Gutiérrez, Á., Sjöström, M. (2007). Cardiovascular fitness in adolescents: the influence of sexual maturation statusthe AVENA and EYHS studies. "American Journal of Human Biology": The Official Journal of the Human Biology Association, 19(6), 801-808.

Orzech J. (1998) Siła mięśni człowieka (w:) Monografie treningu siły mięśniowej. Wyd. Sport i Rehabilitacja

Osiński, W. (1996). Zarys teorii wychowania fizycznego. Wydaw. AWF.

Plewa, M., Markiewicz, A. (2006). Aktywność fizyczna w profilaktyce i leczeniu otyłości. Endokrynologia, Otyłość i Zaburzenia Przemiany Materii, 2(1), 30-37.

Roberts, C. K., Barnard, R. J. (2005). Effects of exercise and diet on chronic disease. "Journal of applied physiology", 98(1), 3-30.

Sozański, H. (1999). Podstawy teorii treningu sportowego. COS, Warszawa, 360.

Szopa, J., Mleczko, E., Żak, S. (1996). Podstawy antropomotoryki Wyd. PWN 2000r. Warszawa-Kraków.

Thune, I. N. G. E. R., Furberg, A. S. (2001). Physical activity and cancer risk: doseresponse and cancer, all sites and site-specific. Medicine and science in sports and exercise, 33(6 Suppl), S530-50.

Warburton, D. E., Nicol, C. W., Bredin, S. S. (2006). Health benefits of physical activity: the evidence. Cmaj, 174(6), 801-809.

Wolff, I., Van Croonenborg, J. J., Kemper, H. C. G., Kostense, P. J., Twisk, J. W. R. (1999). The effect of exercise training programs on bone mass: a meta-analysis of published controlled trials in pre-and postmenopausal women. Osteoporosis international, 9(1), 1-12.

Wood, W., Eagly, A. H. (2012). Biosocial construction of sex differences and similarities in behavior. "In Advances in experimental social psychology" (Vol. 46, pp. 55-123). Academic Press. 